\title{
DESAIN APLIKASI PEMBUATAN SERTIFIKAT PRAKERIN PADA DIVISI HUMAN CAPITAL PT. KRAKATAU IT CILEGON BERBASIS WEBSITE
}

\author{
Ofah Musyarrofah ${ }^{1}$, Sumiyati $^{2}$, Dian Novita ${ }^{3}$ \\ STIKOM Al-Khairiyah Cilegon, Indonesia \\ sayidamusyarrofa@gmail.com ${ }^{1}, \underline{\text { sumiyatiannajmu@gmail.com }}{ }^{2}$, \\ diannovita110197@gmail.com ${ }^{3}$
}

\begin{abstract}
PT. Krakatau Information Technology is a Krakatau Steel Group company based on Electronic Data Processing (EDP) Human Capital Division is a division at PT. Krakatau Information Technology has the task of providing / recruiting employees according to company needs, and this division carries out the task of accepting and guiding work practice participants in accordance with their vocational training work in the industrial worldafter the participants have attended the training for 30 days or 3 months, participants will get a certificate as a sign of carrying out industrial work practices, in the Human Resources Department, PT Kitech's division of making certificates for Industrial Work Practices activities at present is still conventional by using Microsoft Excel and Microsoft Publiser software to manage certificates. The process of making certificates takes a long time to make and there are still many staff who cannot manage and print certificates properly.To overcome this problem, a system was designed that could help to do the job quickly and precisely so as to facilitate the printing of certificates. In designing this system the tools used include Flowmap, Unified Modeling Language (Use Case Diagrams, Class Diagrams, Squence Diagrams, Activity Diagrams), Relationships Between Tables, File Structures, Design of Input Output and Software used are MySQL and Web-based applications, The results of this study are the application of certificates used to facilitate the Human Capital Division in accelerating certificate printing to be more effective and efficient.
\end{abstract}

Keywords: analysis, designing, certificate.

\section{Pendahuluan}

Perkembangan teknologi informasi dari tahun ke tahun selalu mengalami perkembangan yang sangat pesat. Banyaknya fasilitas kemudahan-kemudahan yang ditimbulkan oleh perkembangan teknologi informasi secara langsung berdampak kepada kegiatan organisasi. Dampak dari perkembangan teknologi informasi yang terjadi memacu organisasi-organisasi untuk tetap exist serta dapat meningkatkan prestasi yang dijalankannya. Peran teknologi informasi menitik beratkan pada pengaturan sistem informasi, selain itu teknologi informasi dapat memenuhi kebutuhan 
organisasi dengan sangat cepat, tepat waktu, relevan, dan akurat sesuai dengan pendapat

Menurut Ofah Musyarrofah (2019: 162) sistem yang dibangun dapat membantu manajemen dalam menyajikan informasi yang diperlukan oleh personalia sebagai sarana pendukung keputusan. Permasalahan yang ada pada PT. Krakatau Information Technology di divisi Human Capital dalam pembuatan atau percetakan sertifikat adalah pencetakan sertifikat masih manual dengan aplikasi Ms.Word dan Ms. Excel dan pencatatan peserta praktek kerja dikerjakan dalam bentuk manual. berdasarkan permasalahan yang ada dengan mengacu kepada observasi dilapangan, untuk mengatasi permasalahan maka perlu perancangan aplikasi sertifikat online di divisi Human Capital

Pada divisi Human Resources Departement PT Kitech pembuatan sertifikat untuk kegiatan Praktek Kerja Industri pada saat ini masih bersifat konvensional dengan menggunakan software Microsoft Excel dan Microsoft Publiser untuk mengelola sertifikat. Proses pembuatan sertifikat memakan waktu yang lama dalam pembuatannya, hal ini membuat image divisi Human Capital terkesan lambat serta dianggap tidak serius dalam pengerjaan setifikat tersebut yang notabennya sangat penting untuk seorang siswa/siswi atau mahasiwa/mahasiswi yang menjalani praktek kerja industri di PT Krakatau Information Technology sebagai prasyarat kelulusan mereka.

Aplikasi menurut Dhanta dikutip dari Sanjaya (2015) adalah software yang dibuat oleh suatu perusahaan komputer untuk mengerjakan tugas-tugas tertentu, misalnya Microsoft Word, Microsoft Excel. Aplikasi berasal dari kata application yang artinya penerapan lamaran penggunaan sedangkan menurut Jogiyanto dikutip oleh Ramzi (2013) aplikasi merupakan penerapan, menyimpan sesuatu hal, data, permasalahan, pekerjaan ke dalam suatu sarana atau media yang dapat digunakan untuk menerapkan atau mengimplementasikan hal atau permasalahan yang ada sehingga berubah menjadi suatu bentuk yang baru tanpa menghilangkan nilai-nilai dasar dari hal data, permasalahan, dan pekerjaan itu sendiri Jadi aplikasi merupakan sebuah transformasi dari sebuah permasalahan atau pekerjaan berupa hal yang sulit difahami menjadi lebih sederhana, mudah dan dapat dimengerti oleh pengguna. 
Sehingga dengan adanya aplikasi, sebuah permasalahan akan terbantu lebih cepat dan tepat Langkah yang harus diambil yaitu perlu adanya aplikasi pembuatan sertifikat secara online agar pembuatan sertifikat lebih efektif dan efisien dalam pembuatan aplikasi online ini digunakan metode RnD untuk metode penelitian yang dilakukan

\section{METODE PENELITIAN}

Metode yang digunakan dalam penelitian ini adalah $\mathrm{RnD}$ dimana jenis penelitian dan pengembangan sebuah produk baru atau menyempurnakan produk yang ada, metode penelitian yang dipakai untuk menghasilkan produk tertentu dan menguji keefektifan produk yang dibangun untuk membantu mengatasi permasalahan perancangan aplikasi sertifikat online di divisi Human Capital ,Adapun dalam penelitian ini menggunakan pendekatan kuantitatif, selain itu beberapa metode yang digunakan dalam membantu penyelesaian penelitian ini digunakan juga metode studi literatur, interview dan observasi

\section{Analisis Sistem}

Analisis sistem merupakan penelitian atas sistem yang telah ada dengan tujuan untuk merancang sistem yang baru atau diperbaharui. Menurut Satzinger, J.W , Jackson, R.B., \& burd, S.D (2010) Analisis sistem adalah proses pemahaman dan penentuan secara rinci apa yang seharusnya dicapai oleh sistem informasi. Setelah melakukan pengamatan dan penelitian, penulis menganalisa Di divisi Human Capital PT. Krakatau Information Technology dalam pendataan siswa/siswi dan pencetakan sertifikat prakatek kerja industri (Prakerin) tidak terkomputerisasi atau masih manual menggunakan Microsoft excel dan Microsoft Word. Ketika cetak sertifikat, siswa/siswa prakerin mengisi kembali form data diri dan data sekolahnya hal tersebut kurang efektif dan efisien.

\section{Analisis Kebutuhan Sistem Dan User}

Alternatif pemecahan masalah yang akan ditempuh adalah merancang sebuah aplikasi berbasis web untuk mencatat data siswa/siswi prakerin serta dapat mencetak sertifikat prakerin yang akan dirancang dengan menggunakan $P H P$ (Framework Codeigniter) dan MySQL. Sedangkan analisis pengguna dimaksud 
untuk mengetahui siapa yang berperan sebagai pengguna dalam sistem yang akan dibangun, pengguna dalam sistem aplikasi yang dibangun adalah Divisi Human Capital, bagian yang menjadi administrator aplikasi dan pelaksana proyek

\section{Perancangan Sistem}

Berdasarkan dari hasil pengamatan dan penelitian yang telah dilakukan, maka penulis melakukan usulan untuk merancang aplikasi Sertifikat prakerin Online untuk pendataan dan pencetakan sertifikat siswa/siswi prakerin pada divisi Human Capital di PT. Krakatau Information Technology. Bentuk dari suatu rancangan yang dirancang sedemikian rupa yang memberikan gambaran dan penjelasan untuk menyelesaikan suatu masalah disebut rancangan sistem. Dimana rancangan sistem yang dilakukan tersebut merupakan perbaikan atas sistem yang sedang berjalan. Sehingga dengan dirancangnya sistem yang baru, sistem dapat bekerja lebih efektif dan efisien.

Tahap perancangan sistem ini berupa penggambaran, perancangan dari pembuatan sketsa atau pengaturan dari beberapa elemen yang terpisah kedalam suatu kesatuan yang utuh dan berfungsi, sehingga penulis mencoba mengusulkan perancangan aplikasi sertifikat prakerin online menggunakan PHP (Framework Codeigniter) dan $M y S Q L$, hal ini diupayakan agar mempercepat dalam pencetakan sertifikat siswa/siswi prakerin serta sebagai bentuk upaya dalam budaya paperless untuk data administratif syarat prakerin.

\section{Prosedur Sistem Berjalan}

Prosedur berjalan untuk pendataan dan pencetakan sertifikat siswa/siswi parakerin di Divisi Human Capital pada PT. Krakatau Information Technology yaitu :

a) calon peserta parakerin membawa surat pengajuan prakerin

b) Peserta prakerin menginput form manual data informasi diri dan sekolah

c) Admin menginput data siswa/siswi yang telah mendaftar sebegai peserta prakerin pada dokumen excel

d) Peserta mengiisi form kegiatan sehari-hari sebagai peserta prakerin.

e) Admin mengarsipkan form kegiatan peserta prakerin. 
f) Peserta mengisi from manual untuk cetak sertifkat

g) Admin menginput data peserta untuk cetka serifikat pada dokumen excel

\section{PEMBAHASAN}

Dalam menentukan alur suatu sistem dibutuhkan suatu cara desain untuk mendeskripsikan bagaimana tiap langkah yang dilakukan dalam sistem dan pengguna dapat diketahui sehingga didapatkan gambaran mengenai cara kerja dari sistem yang dibangun berdasarkan alur desain.

\section{Flowmap Berjalan}

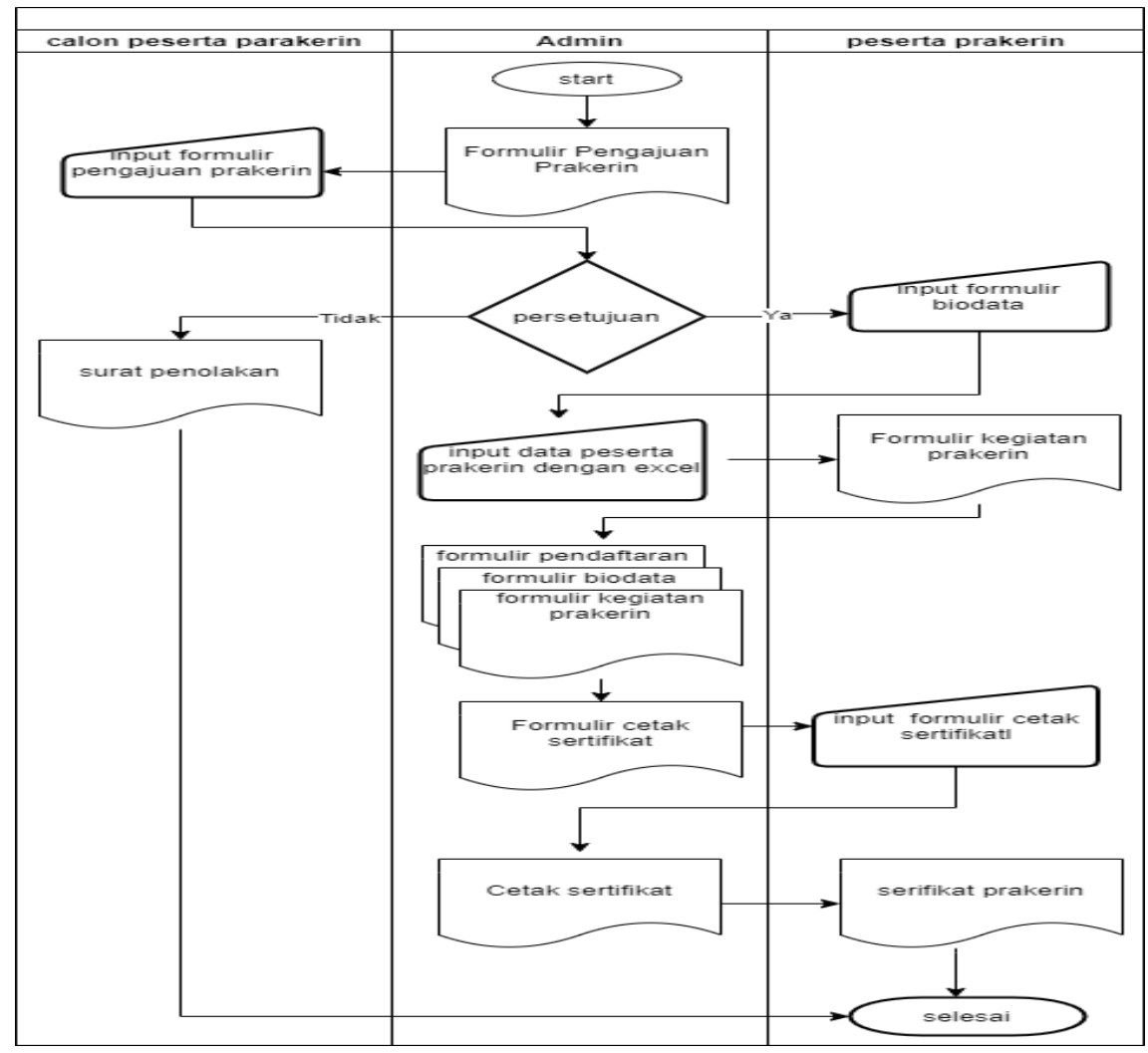

Gambar 1 Flowmap Berjalan 


\section{Flowmap yang diusulkan}

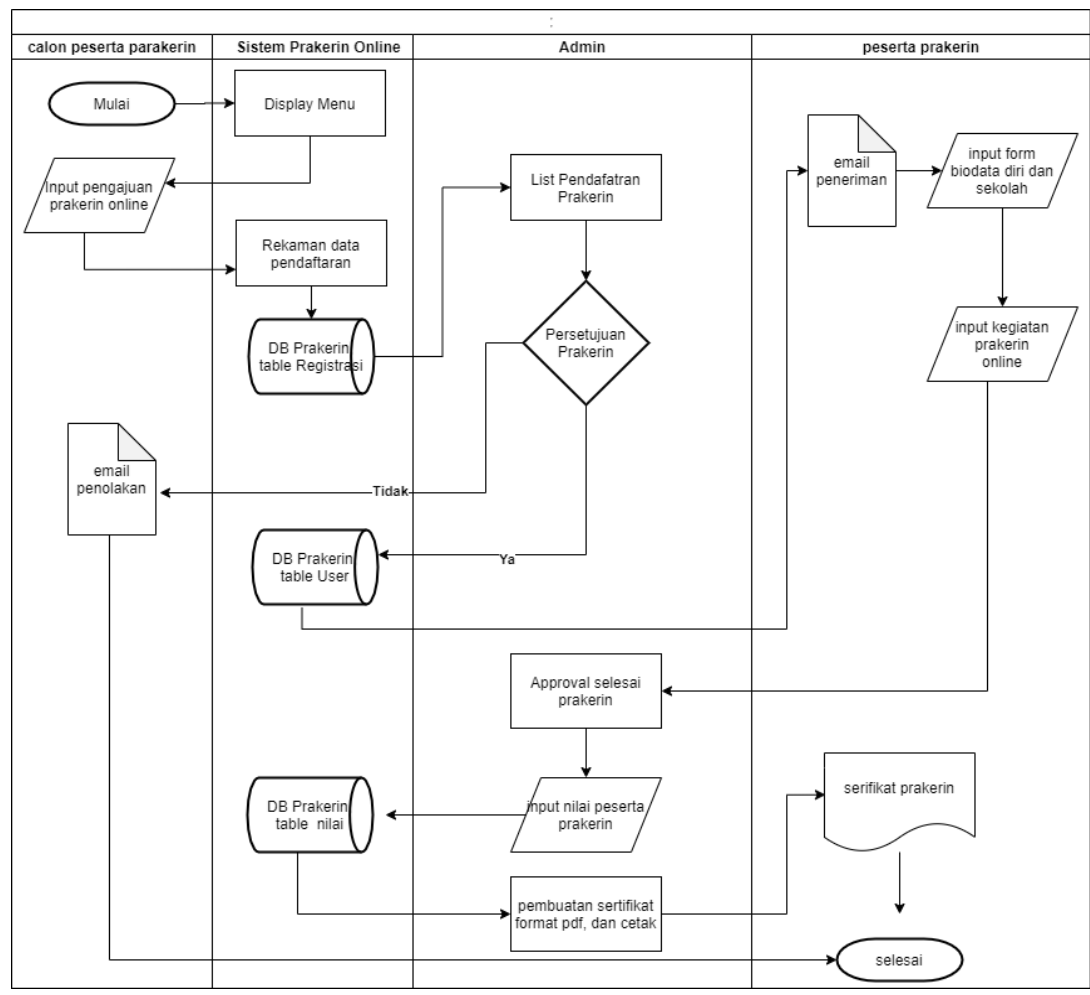

Gambar 2 Flowmap yang diusulkan

\section{Use Case Diagram}

Use case diagram menggambarkan interaksi antar aktor dengan system, supaya diperoleh gambaran mengenai interaksi yang terjadi. berikut ini gambar use case diagram tersebut: 


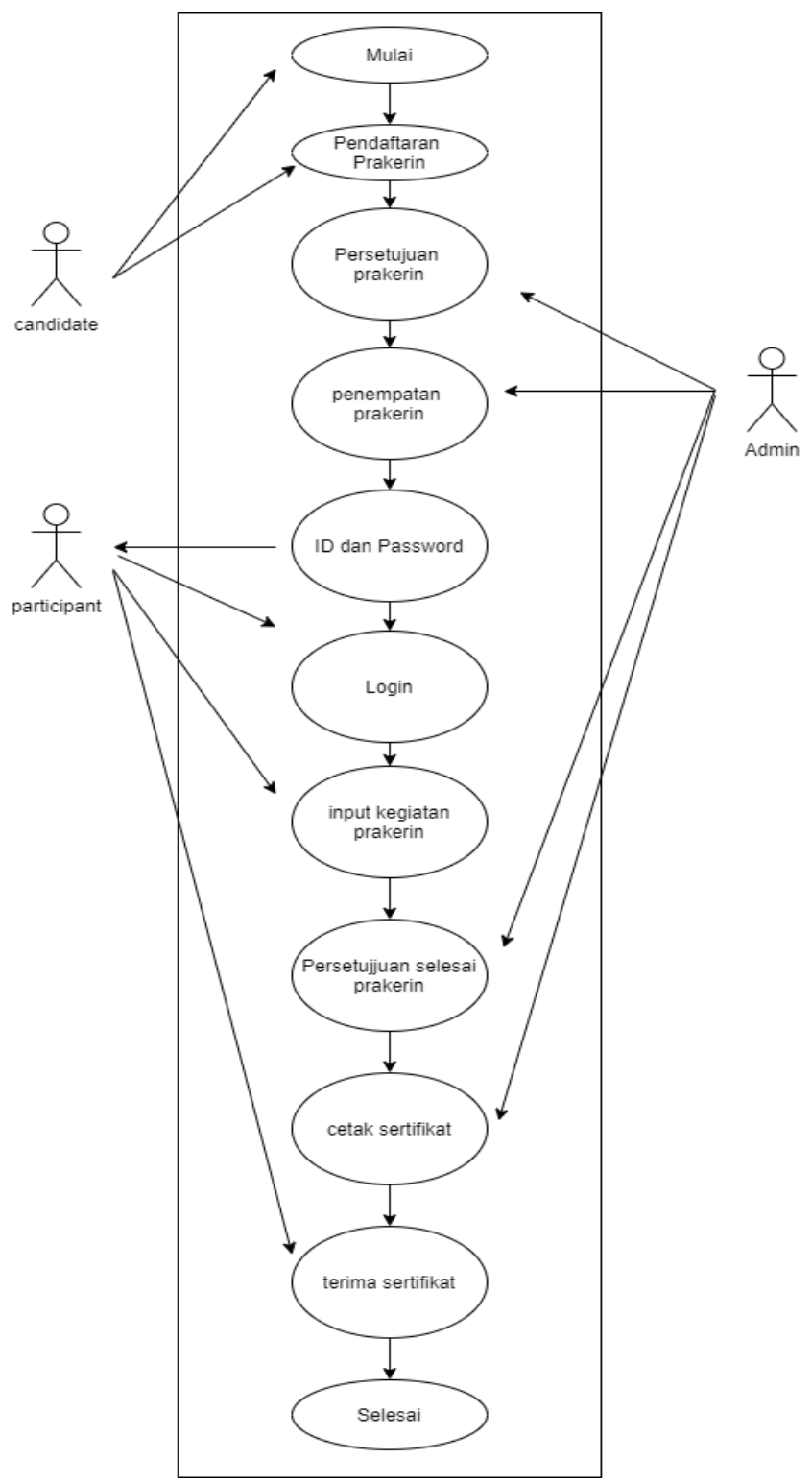

Gambar 3 Use Case Diagram Penggunaan Aplikasi

\section{Class Diagram}

Class diagram memperlihatkan keberadaan dari kelas-kelas dan hubungannya dari sistem dalam logical view. Berikut ini class diagram tersebut. 


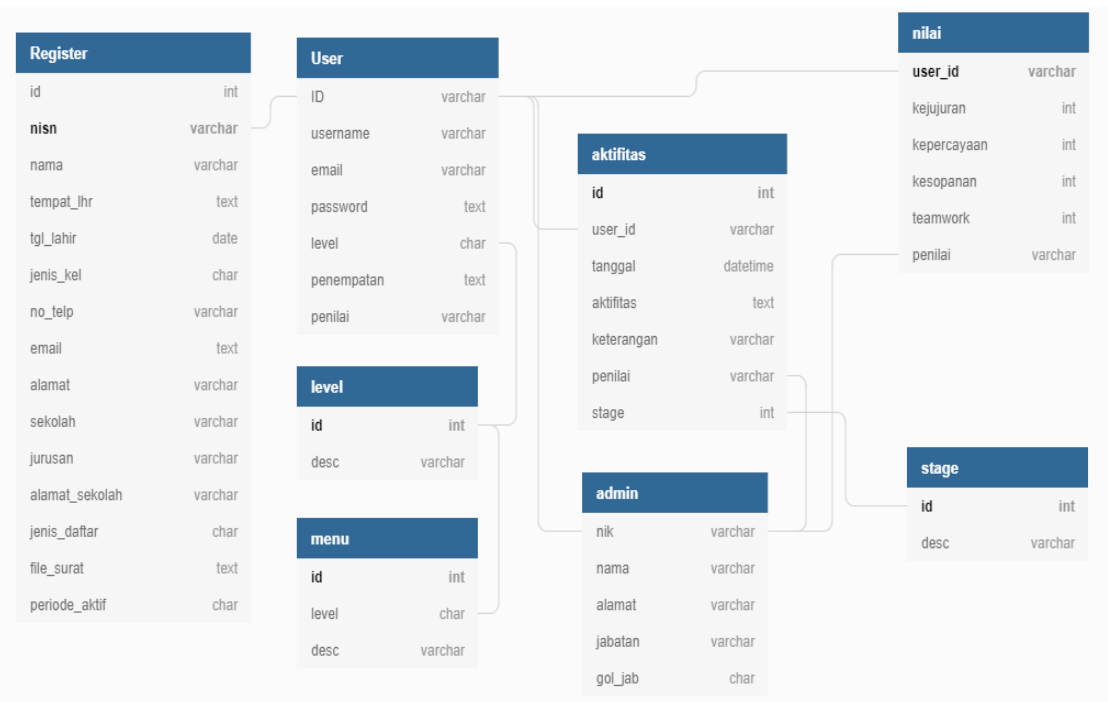

Gambar 4 Class Diagram Database Aplikasi

\section{Activity Diagram}

Activity diagram menggambarkan urutan aktifitas aktor dengan sistem. Berikut ini activity diagram tersebut:

a) Activity Diagram Pendaftarn online

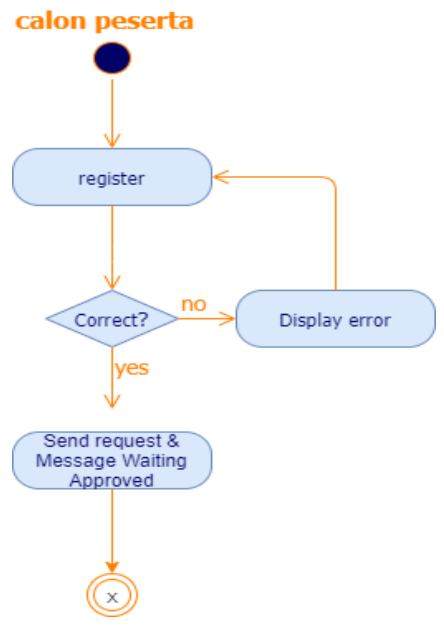

Gambar 5 Activity Diagram Pendaftaran Online 
b) Activity Diagram Penerimaan pedaftaran

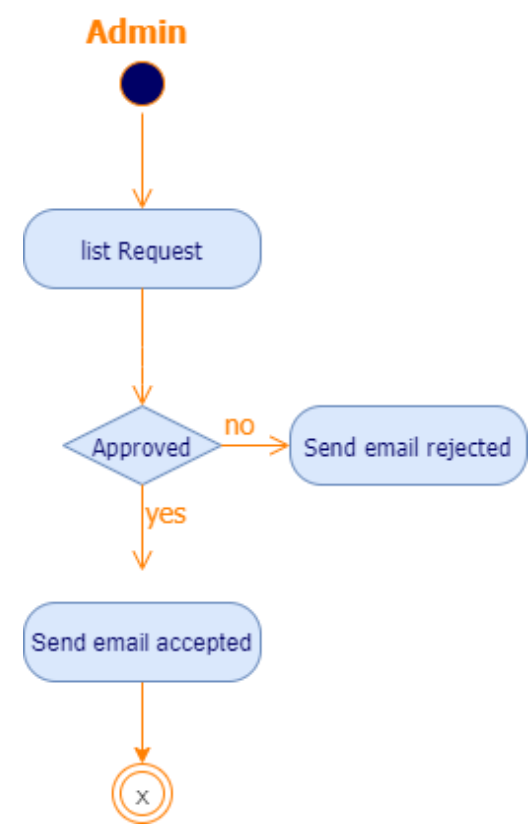

Gambar 6 Activity Penerimaan pedaftaran

\section{c) Activity Diagram Aktifitas peserta}

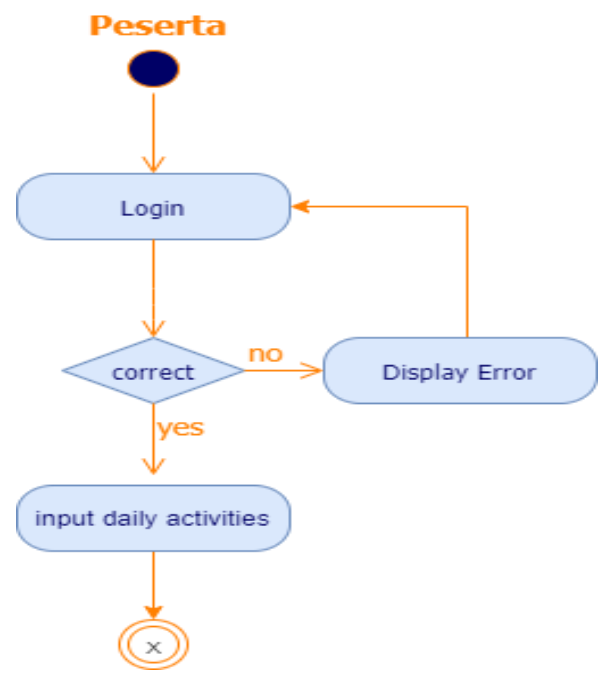

Gambar 7 Activity Diagram Aktifitas Peserta 


\section{d) Activity Diagram penilaian dan Cetak sertifikat}

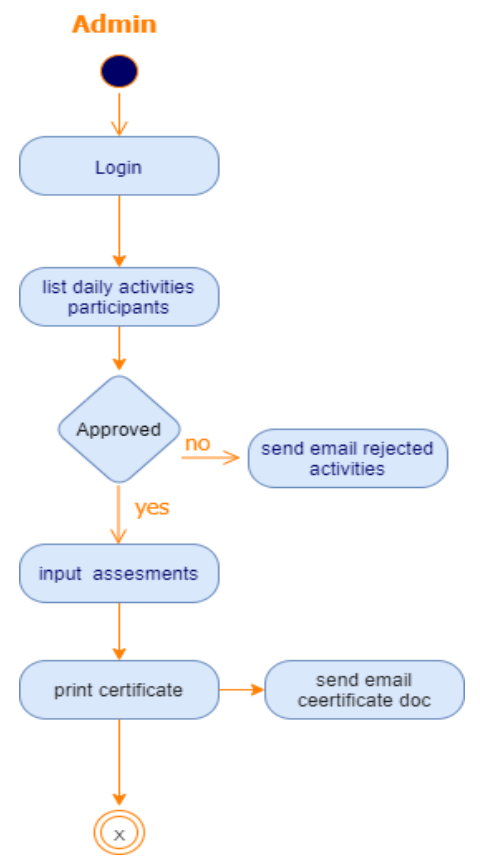

Gambar 8 Activity Diagram penilaian dan Cetak sertifikat

\section{Squence Diagram}

Sequence diagram menampilkan interaksi antar objek didalam sistem pada sebuah urutan atau rangkain waktu. Berikut ini sequence diagram tersebut.

1. Squence Diagram pendaftaran online prakerin

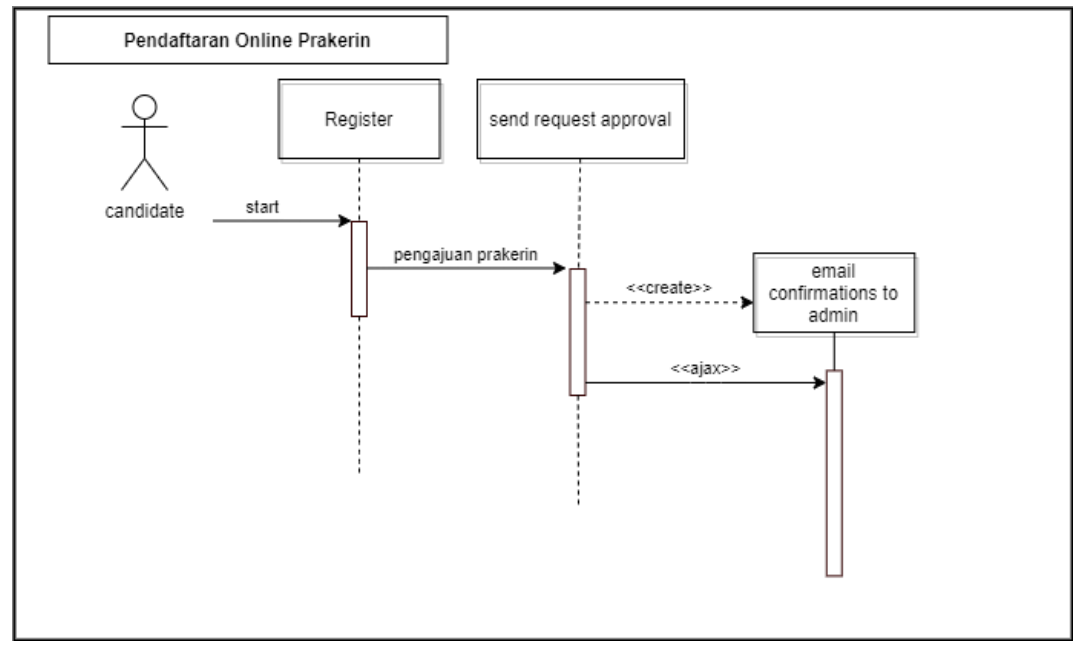

Gambar 9 Squence Diagram Pendaftaran Online Prakerin 
2. Squence Diagram Penerimaan Prakerin

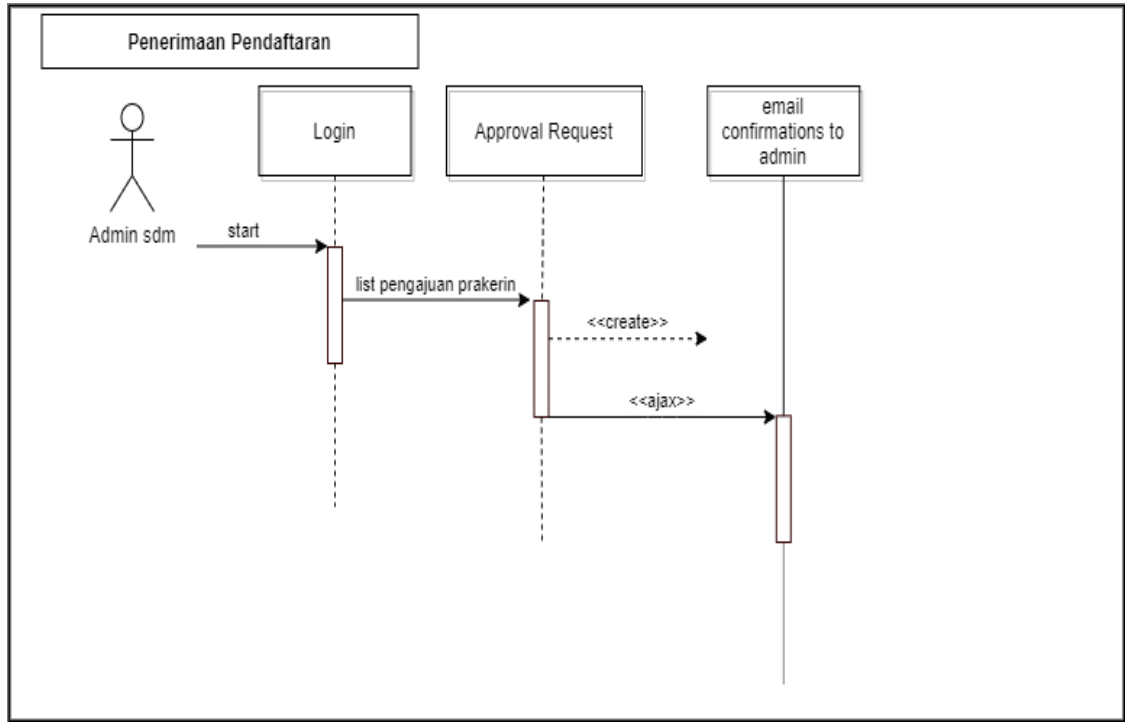

Gambar 10 Squence Diagram Penerimaan Prakerin

3. Squence Diagram Aktifitas Peserta Prakerin

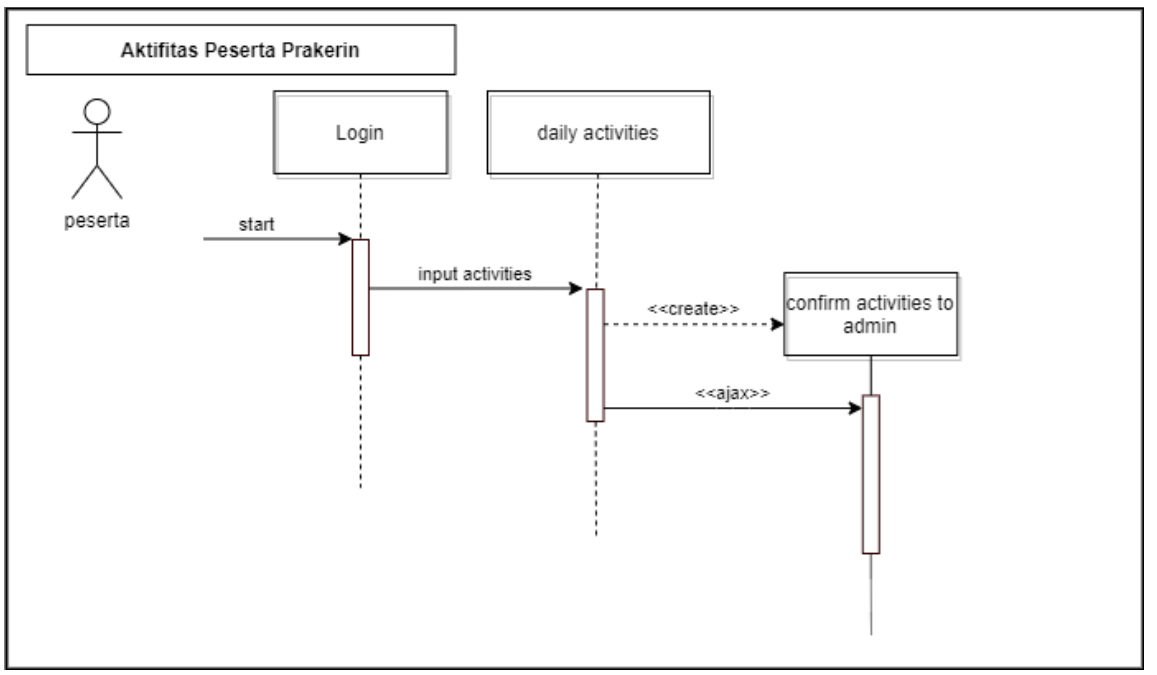

Gambar 11 Squence Diagram Aktifitas Peserta Prakerin 
4. Squence Diagram Penilaian dan Cetak Sertifikat

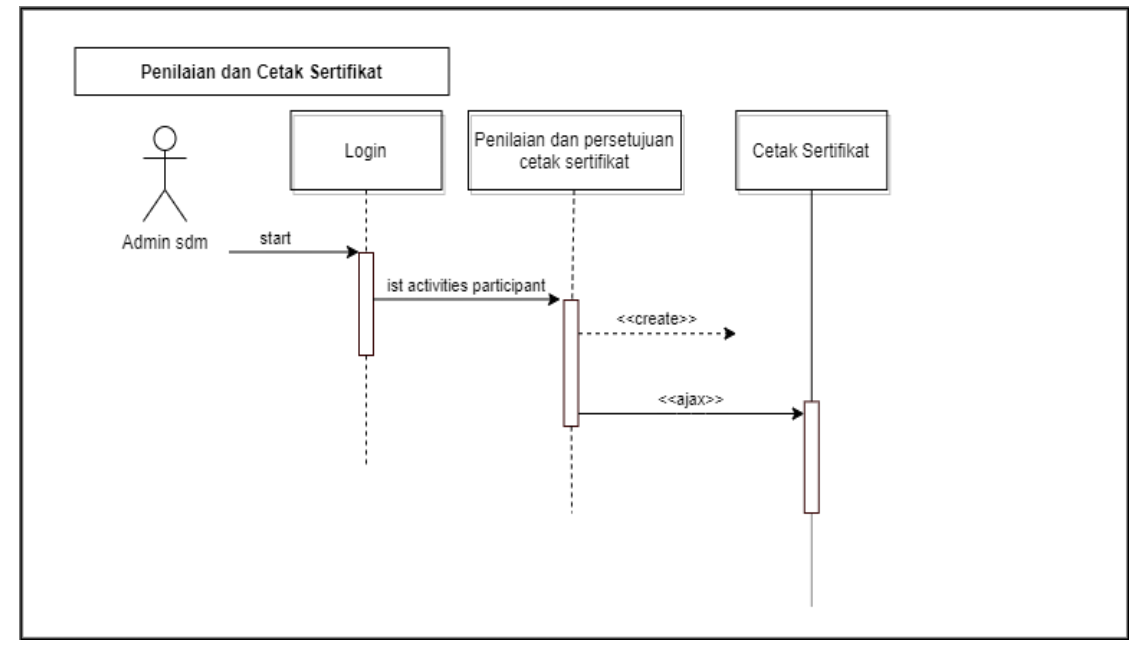

Gambar 12 Squence Diagram Penilaian dan Cetak Sertifikat

\section{Perancangan Basis Data Relasi Antar Tabel}

Relasi antar file merupakan gabungan antar tabel yang mempunyai kunci utama yang sama, sehingga file-file tersebut menjadi satu kesatuan yang dihubungkan oleh field kunci tersebut. Pada proses ini, elemen-elemen data dikelompokkan menjadi satu file database beserta entitas dan hubungannya. Berikut relasi tabel yang diusulkan.

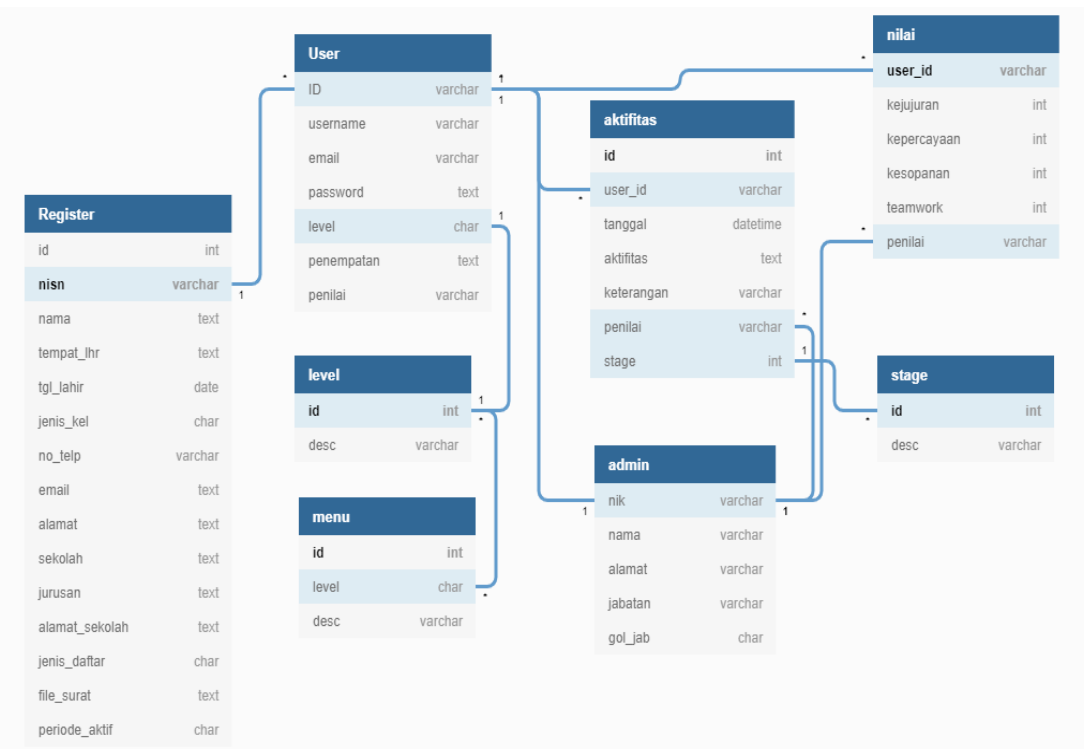

Gambar 13 Relasi Antar Tabel 
Dari gambar relasi antar table diatas dijelaskan bahwa ada 7 tabel yang saling terhubung diantaranya tabel register yang terhubung dengan user dan tabel nilai, tabel user memiliki koneksi dengan tabel level dan menu, sedangkan tabel user terkoneksi dengan tabel aktivitas dan admin selain itu tabel storage terhubung dengan tabel aktivitas dan tabel nilai terhubung dengan tabel admin, untuk atribut dari masing masing dapt dilihat dimasing masing tabel

\section{HASIL}

Perancangan interface/antarmuka yang dimaksudkan adalah rancangan atau desain dari program yang dibuat. Diantaranya mengenai sistem masukan (input), yaitu form-form yang berfungsi untuk menerima dan memasukan data kedalam database. Berikut rancangan desain input yang diusulkan.

\section{Pendaftaran Online Prakerin}

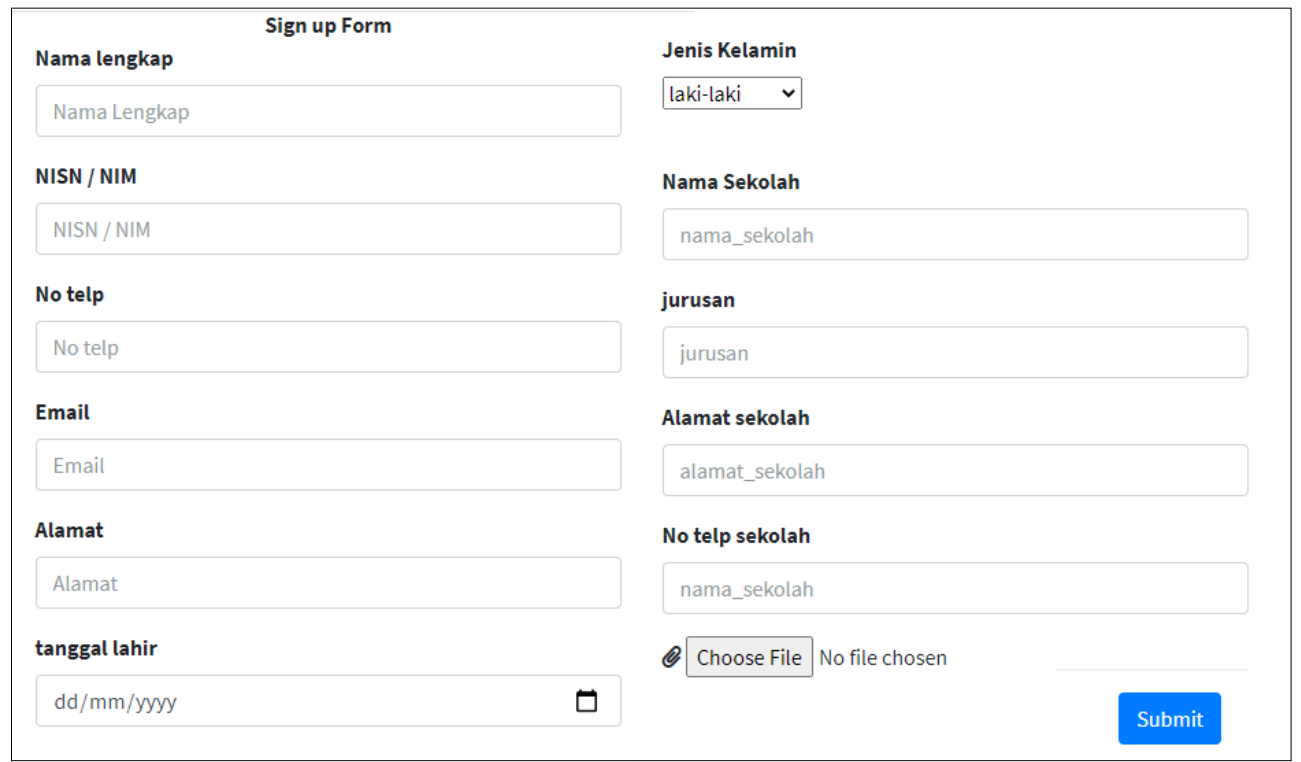

Gambar 14 Antar Muka Pendaftaran Online Prakerin

Dari gambar diatas terlihat formulir pendaftaran prakerin yang harus diisi oleh peserta prakerin diantaranya yang harus dilengkapi adalah nama lengkap, nisn, jenis kelamin, notelp, email, alamat, tanggal lahir, nama sekolah jurusan alamat sekolah dan berkas yang harus dilampirkan untuk disubmit. 


\section{Penerimaan Prakerin}

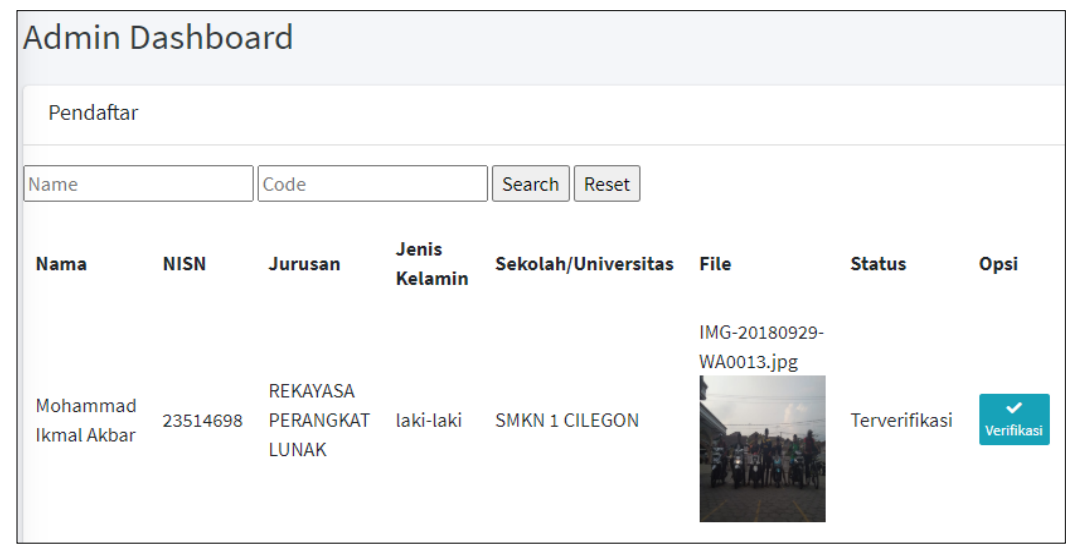

Gambar 15 Antar Muka Penerimaan Prakerin

Dari gambar diatas dapat dilihat bahwa peserta yang sudah mendaftar dan disetujui oleh admin yang sudah melakukan verifikasi akan terekam atribut nama, nisn, jurusan, jenis kelamin, sekolah/ universitas, file dan status, setelah disetujui maka akan ditampilkan aktifitas harian peserta yang akan terlampir pada gambar 16 di bawah.

\section{Rancangan Aktifitas Harian Peserta Prakerin}

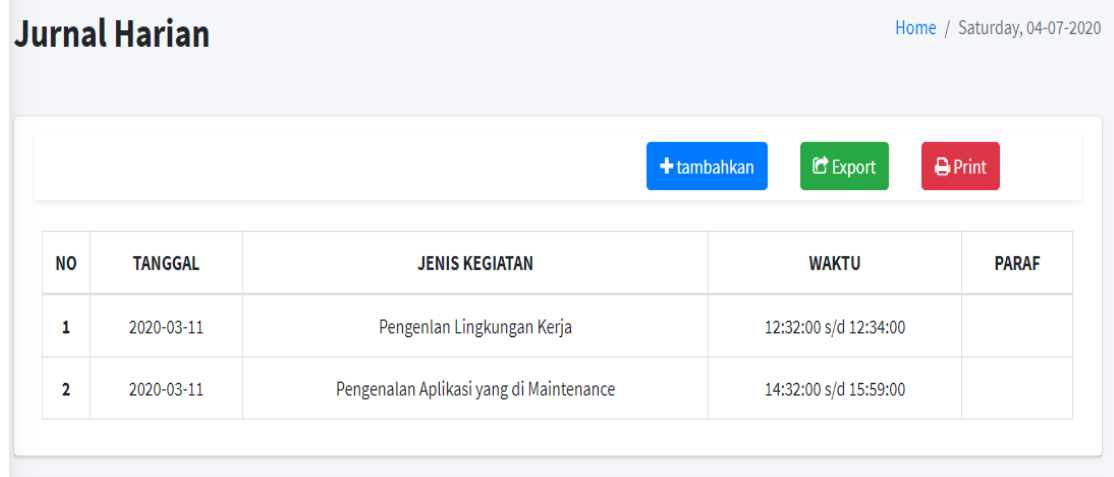

Gambar 16 Antar Muka Atifitas Harian Peserta Prakerin

Menu diatas menggambarkan aktifitas peserta prakerin mulai dari tanggal kegiatan jenis kegiatan waktu dan paraf peserta sehingga terinci semua kegiatan peserta secara baik, setelah digambarkan aktifitas antar muka selanjutnya akan digambarkan mengenai penilaian peserta. 


\section{Rancangan Antar Muka Penilaian}
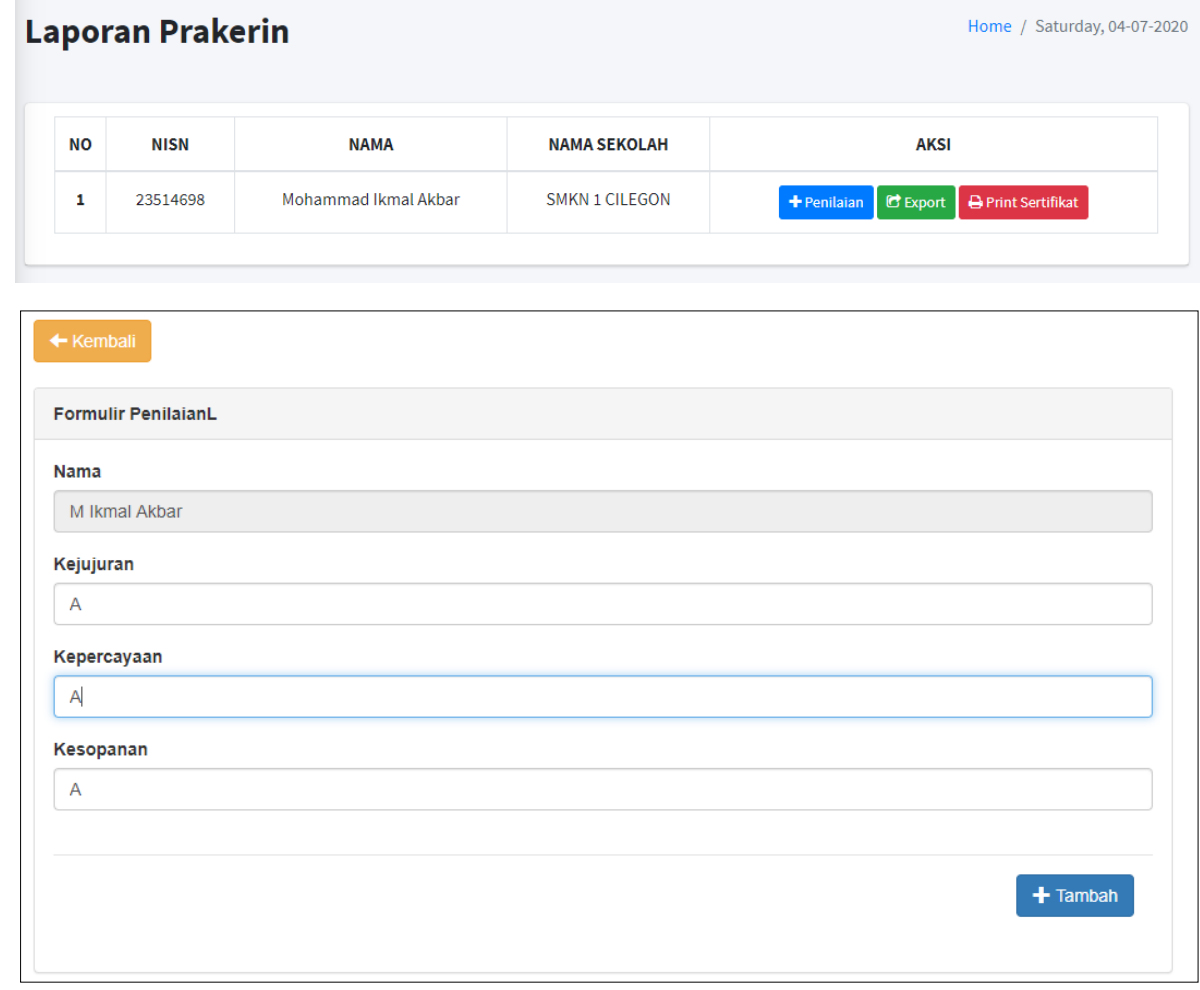

Gambar 17Antar Muka Penilaian

Gambar 17 menggambarkan mengenai penilaian peserta prakerin yang diisi dengan atribut no, nisn, nama, nama sekolah, aksi nilai kejujuran, nilai kepercayaan dan nilai kesopanan dari menu diatas dapat mempermudah pembuatan sertifikat peserta dari sebelum didesain sistem secara online 


\section{Cetak Sertifikat}

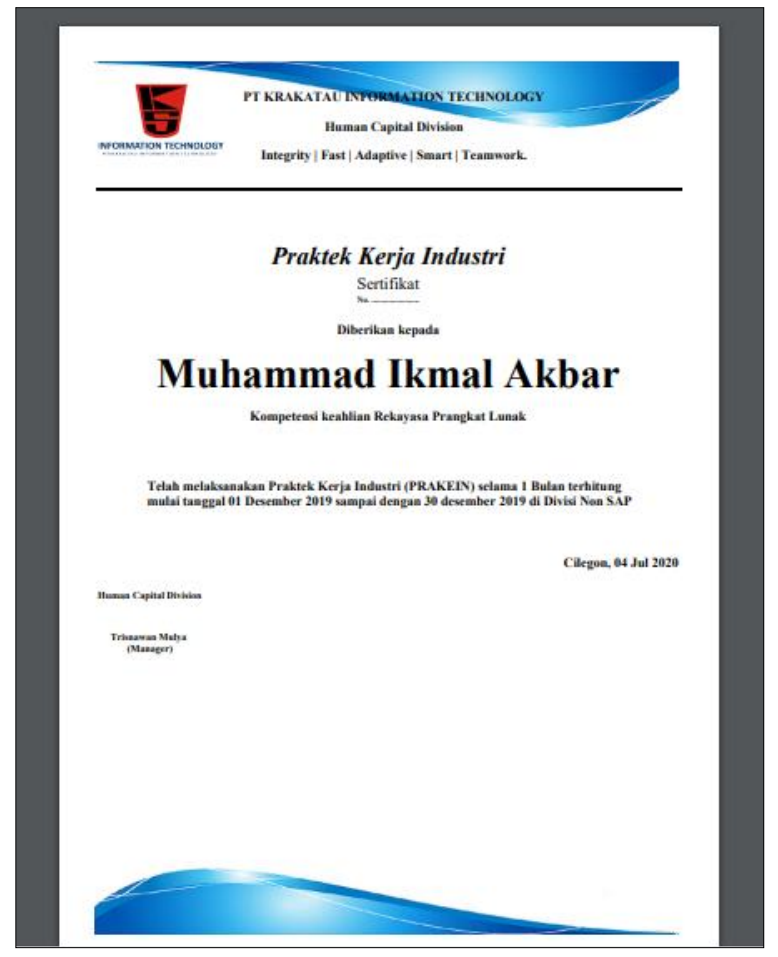

Gambar 18 Cetak Sertifikat

Gambar diatas menggambarkan sertifikat online peserta prakerin yang diajukan secara online oleh peserta dan dibuat oleh admin secara online juga, sehingga lebih cepat waktu dan terorganisir dengan baik,

\section{KESIMPULAN}

Berdasarkan pembahasan pada bab sebelumnya maka dapat ditarik kesimpulan sebagai berikut:

1. Sistem yang dibangun dapat membantu admin mempermudah membuat sertifikat peserta dengan terorganisir dengan baik dengan menggunakan metode $\mathrm{RnD}$ pada PT. Krakatau IT

2. Aplikasi yang dibangun dapat mempermudah peserta dalam mengajukan pendaftaran prakerin yang diadakan oleh PT. Krakatau IT

3. Aplikasi yang dibangun dengan $\mathrm{RnD}$ memberikan manfaat baik untuk peserta maupun perusahan karena proses pembuatan sertifikat lebih cepat dan terstruktur 
dengan baik database nya sehingga informasi yang didapat lebih akurat, cepat dan efisien waktu

4. Perusahaan dapat mengetahui kelemahan sistem lama dan keunggulan sistem yang baru, sehingga sistem baru lebih banyak memberikan solusi dalam pembuatan sertifikat peserta prakerin di PT. Krakatau IT

\section{REFERENCES}

Arka. (2014). Pengertian Contoh Dan Simbol Simbol Flowchart http://tkj.arka.web.id/2014/11/pengertian-contoh-dan-simbol-simbol.html. Akses pada 25 agustus 2020 jam 21.00 WIB

Jogiyanto. 2013. Analisis \& Desain Sistem Informasi : Pendekatan tertruktur teori dan praktik aplikasi bisnis.Andi Offset. Yogyakarta.

Kadir, abdul. (2014). Pengenalan Sistem Informasi Edisi Revisi, Penerbitan Andi Publisher, Yogyakarta.

Kristanto Andri. 2008. Perancangan Sistem Informasi dan Aplikasinya. Gava Media. Yogyakarta

Madcoms, Litbang (2011). Aplikasi Web Database Dengan Dreamweaver dan php MySQL. Yogyakarta: Andi

Maturidi, Ade Johar. 2014. Metode Penelitian, Penerbit Deepublish, Yogyakarta

Mulyani, Sri. 2016. Metode Analisis dan Perancangan Sistem, Penerbit Abdi Sistematika, Bandung.

Musyarrofah, O. (2019). Implementasi Decision Support System Seleksi Penerimaan Pegawai Baru Pada Cv. Cipta Totalindo Prima. Journal of Innovation and Future Technology (IFTECH), 1(2), 162-177.

P. A. E. Pratama. 2014. Sistem Informasi dan Implementasinya, Penerbit Bandung Informatika, Bandung.

S Rosa, dan M. Salahudin, (2014), Rekayasa Perangkat Lunak Struktur Berorientasi Objek. Bandung : Informatika

Sanjaya (2015). Model Pengajaran dan Pembelajaran, Bandung: CV Pustaka Setia

Sutanta edhy, Pengantar Teknologi Informasi, Yogyakarta : Gremedia 2005

Triandini, evi \& Suardik, 2012. Step by Step Desaign Proyek Menggunakan UML, Yogyakarta : Andi. 